\title{
Significant Genotype Difference in the CYP2E1 PstI Polymorphism of Indigenous Groups in Sabah, Malaysia with Asian and Non-Asian Populations
}

\author{
Lucky Poh Wah Goh ${ }^{1}$, Eric Tzyy Jiann Chong ${ }^{1}$, Kek Heng Chua ${ }^{2}$, Jitt Aun \\ Chuah $^{3}$, Ping-Chin Lee ${ }^{1 *}$
}

\begin{abstract}
CYP2E1 PstI polymorphism G-1259C (rs3813867) genotype distributions vary significantly among different populations and are associated with both diseases, like cancer, and adverse drug effects. To date, there have been limited genotype distributions and allele frequencies of this polymorphism reported in the three major indigenous ethnic groups (KadazanDusun, Bajau, and Rungus) in Sabah, also known as North Borneo. The aim of this study was to investigate the genotype distributions and allele frequencies of the CYP2E1 PstI polymorphism G-1259C in these three major indigenous peoples in Sabah. A total of 640 healthy individuals from the three dominant indigenous groups were recruited for this study. Polymerase chain reaction-restriction fragment length polymorphism (PCR-RFLP) at G-1259C polymorphic site of CYP2E1 gene was performed using the $P$ st I restriction enzyme. Fragments were analyzed using agarose gel electrophoresis and confirmed by direct sequencing. Overall, the allele frequencies were $90.3 \%$ for $c 1$ allele and $9.7 \%$ for $c 2$ allele. The genotype frequencies for $c 1 / c 1, c 1 / c 2$ and $c 2 / c 2$ were observed as $80.9 \%, 18.8 \%$, and $0.3 \%$, respectively. A highly statistical significant difference ( $\mathbf{p}<0.001)$ was observed in the genotype distributions between indigenous groups in Sabah with all Asian and non-Asian populations. However, among these three indigenous groups, there was no statistical significant difference $(p>0.001)$ in their genotype distributions. The three major indigenous ethnic groups in Sabah show unique genotype distributions when compared with other populations. This finding indicates the importance of establishing the genotype distributions of CYP2E1 PstI polymorphism in the indigenous populations.
\end{abstract}

Keywords: CYP2E1 - PstI polymorphism - indigenous population - Sabah ethnic groups

Asian Pac J Cancer Prev, 15 (17), 7377-7381

\section{Introduction}

The human $C Y P 2 E 1$ gene is the only subfamily of human cytochrome P450 E (Zhuge et al., 2003), located on chromosome 10q24.3-qter. CYP2E1 plays an important role in the metabolic pathway of toxicants, procarcinogens, drugs and produce high levels of reactive oxygen species that lead to formation of cancerous cell (Nakazawa et al., 1996; Wu and Cederbaum, 1996; McCord, 1998). CYP2E1 gene contains several genetic polymorphisms identified by RFLPs using restriction enzymes such as, Dra I, Rsa I, Pst I, and Taq I. These polymorphisms have been associated with various human cancers such as lung cancer, esophageal cancer, breast cancer, colorectal cancer and cigarette smoking-related hepatocarcinogenicity (Uematsu et al., 1992; Raunio et al., 1995; Wu et al., 1997; Lin et al., 1998; Saeed et al., 2013). CYP2E1 polymorphisms also had an effect towards drug reactions such as the pathogenesis of anti-tuberculosis drug-induced hepatotoxicity (ATDH) in several populations (An et al., 2012; Gupta et al., 2013). Despite of the various single nucleotide polymorphisms (SNPs) identified, Pst I and Rsa I polymorphisms are in complete linkage disequilibrium (Maezawa et al., 1994).

CYP2E1 PstI polymorphism (rs3813867) is a ' $\mathrm{G}$ ' nucleotide to ' $C$ ' nucleotide change at 1259 position in the 5 '-flanking region of the gene. This polymorphism can affect the transcription level of $C Y P 2 E 1$ gene in vitro and its enzyme activity (Haufroid et al., 2002). Individuals with at least one $c 2$ allele and exposed to risk factors increase susceptibility to gastric or colorectal cancer (Cai et al., 2001; Kiss et al., 2007; Feng et al., 2012). However, this polymorphism decreases the risk to esophageal cancer (Haufroid et al., 2002) and lung cancer (Wang et al., 2014).

Population differences in the expression of CYP2E1 gene that lead to malignancy, therapeutic failure and severe toxicity have been connected to its polymorphism. The genotype distribution and allele frequencies of

${ }^{1}$ Biotechnology Programme, Faculty of Science and Natural Resources, Universiti Malaysia Sabah, Jalan UMS, Kota Kinabalu, Sabah, ${ }^{2}$ Department of Biomedical Science, Faculty of Medicine, University of Malaya, Kuala Lumpur, ${ }^{3}$ Department of Surgery, Queen Elizabeth Hospital, Kota Kinabalu, Sabah, Malaysia*For correspondence: leepc@ums.edu.my 
CYP2E1 polymorphism differ significantly across different populations (Bolt et al., 2003; Shahriary et al., 2012; Lakkakula et al., 2013). In Malaysia, there is a high prevalence of nasopharyngeal cancer in the major indigenous groups and high cases of tuberculosis in Sabah (Rundi et al., 2011). Thereby, understanding of population differences in allele and genotype frequencies have the potential to explain some variability to cancer susceptibility, improve clinical practice, and evaluate variability of drug response in these populations.

Sabah is one of the 13 states in Malaysia, is located in Borneo Island and also known as North Borneo has approximately 3.3 million populations, comprising of 32 ethnic groups, out of 28 are indigenous (Wise, 2008). The three major indigenous ethnics in Sabah are KadazanDusun, Bajau, and Rungus (Hans et al., 2008; Leete, 2008).

The CYP2E1 polymorphism is well studied in other populations, but very limited study was observed for Malaysian populations. Previous findings of the CYP2E1 polymorphism association study only include Malays, Chinese, and Indians as they are the three major ethnic groups of Malaysia (Kandasami et al., 2003), but did not include the three major indigenous ethnic groups originated from East Malaysia, Sabah. The present study aimed to provide basic information about the genotype distributions and allele frequencies of CYP2E1 PstI polymorphism in the three major indigenous populations in Sabah that could give an insight for the variability of drug response and cancer susceptibility in future.

\section{Materials and Methods}

\section{Study population and DNA isolation}

Blood samples were collected from 640 subjects who are not genetically related and were selected randomly during several blood donation campaigns from February 2011 till January 2013. Informed consent was obtained from subjects prior to venous blood collection for this cohort study. DNA was isolated from $2 \mathrm{~mL}$ of whole blood using alkaline lysis method and stored at $-20^{\circ} \mathrm{C}$. This study was approved by the Department of Health in Sabah and ethical approval for this study was obtained from University Malaya Medical Centre (UMMC) Ethical Board with Ref. 654.1.

\section{Genetic analysis}

The CYP2E1 PstI polymorphism (rs3813867) was determined by PCR-RFLP using sense (5'-CCAGTCGAGTCTACATTGTCA-3') and antisense (5'-TTCATTCTGTCTTCTAACTGG-3') primers as previously described (Hayashi et al., 1991). A total of $20 \mu \mathrm{L}$ PCR reaction mixture contained $100 \mathrm{ng}$ of DNA template, $0.2 \mu \mathrm{M}$ of each primers, $1.5 \mathrm{mM}$ of $\mathrm{MgCl}_{2}$, $0.2 \mathrm{mM}$ of dNTPs, 1X PCR Buffer, and 1 unit of Go $T a q^{\circledR}$ Flexi DNA polymerase (Promega, USA). PCR was performed with the following conditions: $5 \mathrm{~min}$ at $94^{\circ} \mathrm{C}$, 35 cycles of $94^{\circ} \mathrm{C}$ for 30 seconds, $58^{\circ} \mathrm{C}$ for 30 seconds, and $72^{\circ} \mathrm{C}$ for $1 \mathrm{~min}$, followed by final cycle at $72^{\circ} \mathrm{C}$ for 7 min. The PCR products were subjected to digestion using 5 units of Pst I (New England BioLabs ${ }^{\circledR}$ Inc., Ipswich,
MA) restriction enzyme per $15 \mu \mathrm{L}$ reaction mixture and incubated at $37^{\circ} \mathrm{C}$ for 16 hours. The digested products were analyzed by electrophoresis in a $2.0 \% \mathrm{EtBr}$ stained agarose gel in $1 \mathrm{X}$ TAE buffer. The presence of restriction site yielded fragments of $120 \mathrm{bp}$ and $290 \mathrm{bp}$ corresponding to $c 2 / c 2$ genotype (variant); $410 \mathrm{bp}, 120 \mathrm{bp}$, and $290 \mathrm{bp}$ corresponding to $c 1 / c 2$ genotype (heterozygous). A $410 \mathrm{bp}$ corresponding to $c 1 / c 1$ genotype (wild-type) was observed in the absence of restriction site. PCR-amplified DNA samples were subjected to direct sequencing using ABI PRISM $^{\circledR} 3100$ Genetic Analyzer (Applied Biosystems, USA) to further confirm the CYP2E1 Pst I polymorphism.

\section{Statistical analysis}

SPSS Software V17.0 (SPSS Inc., Chicago, Illinois) was used in the statistical analysis. The Hardy-Weinberg equilibrium (HWE) for each population was determined using "Chi-Square" $\left(\chi^{2}\right)$ test at 5\% significant level and degree of freedom $=1$. The results of this study were compared with other populations by the same test. A $\mathrm{p}<0.05$ is considered statistically significant and $\mathrm{p}<0.001$ is highly statistical significant.

\section{Results and Discussion}

The 640 subjects consists of 361 KadazanDusun (219 males and 142 females), 154 Bajau (122 males and 32 females), and 125 Rungus (65 males and 60 females). The age of the subjects ranged from 13 to 80 years old with the mean age \pm S.D. of $28.7 \pm 15.4$ (Table 1 ). The genotype distributions for KadazanDusun, Bajau, Rungus, and total sum of the subjects in this study did not deviate from HWE ( $p>0.05$ ). The heterozygosity and homozygosity of this SNP was confirmed by direct sequencing.

The $c 1$ and $c 2$ allele frequencies of CYP2E1 PstI polymorphism of this study were $90.3 \%$ and $9.7 \%$, respectively. The genotype frequencies of this study were $80.9 \%$ for $c 1 / c 1,18.8 \%$ for $c 1 / c 2$, and $0.3 \%$ for $c 2 / c 2$ genotypes. The genotype frequency of $c 1 / c 1$ was highly observed in these populations followed by $c 1 / c 2$ and $c 2 /$ $c 2$ genotypes (Table 2). Similar genotype distribution was observed in KadazanDusun, Bajau and Rungus ethnic groups (Table 1). Genotype $c 2 / c 2$ was not observed in Bajau and Rungus ethnic groups.

CYP2E1 PstI polymorphism shows variability among different populations and ethnicities backgrounds. This plays a significant contribution to the individual differences in the predisposition of disease development and adverse drug reactions (Costa et al., 2012). CYP2E1 polymorphisms in different populations have shown a different risk factor towards anti-tuberculosis druginduced hepatotoxicity (Lee et al., 2010). In addition, susceptibility to disease such as cancer for individuals and ethnic groups can be investigated using genetic markers like SNPs (Danko and Chaschin, 2005). Hence, this is the first study to document the genotype distributions and allele frequencies of CYP2E1 PstI polymorphism in the indigenous East Malaysia populations with a large sample size. This study provides the first insight to the future prospects of genetic variation associated with $C Y P 2 E 1$ PstI polymorphism in the indigenous Sabah populations. 
There were no genotype distributions differences ( $p>0.001$ ) among the KadazanDusun, Bajau, and Rungus in this study (Table 1). This suggests that they are closely related in their genetic composition which was in line with the population studies based on Alu insertions of the same indigenous groups in Sabah (Kee et al., 2012). Therefore, these ethnic groups could share the same level of disease predisposition and drug metabolizing effects.

The study of CYP2E1 PstI polymorphism could be clinically important as the prediction of adverse drug reactions by genotyping of drug-metabolizing enzymes has the potential in drug and dosage determination in the beginning of therapy. The CYP2E1 gene had shown to encode enzyme that is involved in the metabolism of several drugs such as paracetamol, chlorzoxazone and ethanol (Agundez et al., 1997). Investigators reported that Japanese (Kim et al., 1996) had a lower oral clearance of the chlorzoxazone (in vivo probe) when compared with Caucasians. Hence, the indifference of genotype distributions in the three major indigenous groups of this study may also suggest that they could share similar drug reactions or metabolism but differ from Japanese or Caucasian.

Studies on SNPs might reveal valuable population data regarding the relationships that share among different

Table 1. Distribution of Selected Variables in this Study

\begin{tabular}{|c|c|c|c|c|}
\hline & $\begin{array}{l}\operatorname{adazanDusun}^{\mathrm{a}} \\
(\mathrm{N}=361) \\
\mathrm{N}(\%)\end{array}$ & $\begin{array}{c}\text { Bajau }^{\mathrm{b}} \\
(\mathrm{N}=154) \\
\mathrm{N}(\%)\end{array}$ & $\begin{array}{c}\text { Rungus }^{\mathrm{b}} \\
(\mathrm{N}=125) \\
\mathrm{N}(\%)\end{array}$ & $\begin{array}{c}\text { Total } \\
(\mathrm{N}=640), \\
\mathrm{N}(\%)\end{array}$ \\
\hline \multicolumn{5}{|l|}{ Age } \\
\hline$<50$ & $311(86.2)$ & 133 (86.4) & $112(89.6)$ & $556(86.9)$ \\
\hline$\geq 50$ & $50(13.8)$ & $21(13.6)$ & $13(10.4)$ & $84(13.1)$ \\
\hline Mean \pm SD & $29.2 \pm 15.7$ & $30.9 \pm 13.5$ & $24.4 \pm 15.7$ & $28.7 \pm 15.4$ \\
\hline Range & $16-80$ & $17-76$ & $13-71$ & $13-80$ \\
\hline \multicolumn{5}{|l|}{ Gender } \\
\hline Male & $219(60.7)$ & $122(79.2)$ & $65(52.0)$ & $406(63.4)$ \\
\hline Female & $142(39.3)$ & $32(20.8)$ & $60(48.0)$ & $234(36.6)$ \\
\hline \multicolumn{5}{|l|}{ Allele } \\
\hline $\mathrm{c} 1$ & 654 (90.6) & 285 (92.5) & 217 (86.8) & $1156(90.3)$ \\
\hline c2 & $68(9.4)$ & $23(7.5)$ & $33(13.2)$ & 124 (9.7) \\
\hline \multicolumn{5}{|l|}{ Genotype } \\
\hline $\mathrm{c} 1 / \mathrm{c} 1$ & 295 (81.7) & $131(85.1)$ & $92(73.6)$ & $518(80.9)$ \\
\hline $\mathrm{c} 1 / \mathrm{c} 2$ & $64(17.7)$ & $23(14.9)$ & $33(26.4)$ & $120(18.8)$ \\
\hline $\mathrm{c} 2 / \mathrm{c} 2$ & $2(0.6)$ & $0(0.0)$ & $0(0.0)$ & $2(0.3)$ \\
\hline $\operatorname{HWE}\left(\mathrm{X}^{2}\right)^{*}$ & $*$ & 0.55 & 2.89 & 3.28 \\
\hline
\end{tabular}

populations (Kayaalti and Soylemezoglu, 2010). In a combination analysis of the indigenous populations in Sabah, the CYP2E1 PstI genotype distributions were compared with Asians (Chinese, Korean and Taiwanese) and non-Asians (Brazilian, Caucasian, French and Hungarian) populations. As shown in Table 2, there was a highly statistical significant difference $(\mathrm{p}<0.001)$ in the genotype distributions of the indigenous ethnics in Sabah when compared with all Asians and non-Asians populations. This implicates that the evolutionary course changes the distributions of autosomal chromosome CYP2E1 PstI SNP in human populations even though the three major indigenous ethnic groups in Sabah could be descendants from Southern China (Kee et al., 2012).

The $c 1 / c l$ genotype frequency of this study $(80.9 \%)$ was relatively similar to Chinese (Feng et al., 2012) (73.3\%), but relatively higher than Taiwanese (Yu et al., 1995) (63.3\%) and Korean (Park et al., 2003) (64.8\%) populations. However, all non-Asian populations had a significantly higher $c 1 / c 1$ genotype frequency $(>90 \%)$ when compared with Asian and ethnic groups of Sabah in the current study. The $c 1 / c 2$ genotype frequency of the indigenous populations in Sabah $(18.8 \%)$ was less prominent when compare with other Asian populations but relatively similar to the Chinese population (Feng et al., 2012) (23.3\%). On the contrary, all Asians populations including the indigenous Sabah populations of this study had a significantly higher $c 1 / c 2$ genotype frequency when compared with all non-Asian populations (Caucasian, Hungarian, French, and Brazilians). The $c 2 / c 2$ genotype frequency of indigenous ethnics in Sabah $(0.3 \%)$ was the lowest among Asian populations. An exception of Chinese (Guo et al., 2008) population showed a significantly high $c 2 / c 2$ genotype frequency (15.6\%) when compared with all other Asian and non-Asian populations. These differences of genotype frequencies in a population play an important role in the development of personalized medicine as different genotype might metabolize drug slightly different.

CYP2E1 polymorphism had been shown to be associated with disease susceptibility and several types of chemical-induced diseases (Wu et al., 1998; Liu et al., 2001; Deng et al., 2014). The $c 2 / c 2$ genotype was associated to the increased risk of gastric cancer in Korean (Park et al., 2003) and Chinese (Feng et al.,

Table 2. CYP2E1 PstI Genotype Distributions across Different Populations

\begin{tabular}{|c|c|c|c|c|c|}
\hline & \multirow[t]{2}{*}{ Study } & \multirow[t]{2}{*}{ Population } & \multicolumn{3}{|c|}{ Genotype, N (\%) } \\
\hline & & & $\mathrm{c} 1 / \mathrm{c} 1$ & $\mathrm{c} 1 / \mathrm{c} 2$ & $\mathrm{c} 2 / \mathrm{c} 2$ \\
\hline \multirow[t]{6}{*}{ Asian } & Present Study & East Malaysian $^{\mathrm{a}}$ & $518(80.9)$ & $120(18.8)$ & $2(0.3)$ \\
\hline & Yu et al. 1995 & Taiwanese $^{\mathrm{b}}$ & $95(63.3)$ & $49(32.7)$ & $6(4.0)$ \\
\hline & Park et al. 2003 & Korean $^{\mathrm{b}}$ & $94(64.8)$ & $48(33.1)$ & $3(2.1)$ \\
\hline & Guo et al. 2008 & Chinese $^{\mathrm{b}}$ & $225(46.9)$ & $180(37.5)$ & $75(15.6)$ \\
\hline & Feng et al. 2012 & Chinese $^{\mathrm{b}}$ & $374(73.3)$ & $119(23.3)$ & $17 \quad(3.3)$ \\
\hline & Lakkakula et al. 2013 & South Indian ${ }^{\mathrm{b}}$ & 207 (97.6) & $5(2.4)$ & $\begin{array}{ll}0 & (0.0)\end{array}$ \\
\hline \multirow[t]{5}{*}{ Non-Asian } & van der Logt et al. 2006 & Caucasian $^{\mathrm{b}}$ & $389(94.4)$ & $21 \quad(5.1)$ & $2(0.5)$ \\
\hline & Kiss et al. 2007 & Hungarian ${ }^{\mathrm{b}}$ & $456(91.2)$ & $42 \quad(8.4)$ & $2(0.4)$ \\
\hline & Küry et al. 2007 & French $^{\mathrm{b}}$ & $1029(92.0)$ & $88 \quad(7.9)$ & $1(0.1)$ \\
\hline & Rossini et al. 2007 & Brazilians $^{\mathrm{b}}$ & $230(92.7)$ & $15(6.1)$ & $3(1.2)$ \\
\hline & Catterchio et al. 2008 & Caucasian $^{\mathrm{b}}$ & $1162(93)$ & 85 (7) & $0 \quad(0.0)$ \\
\hline
\end{tabular}

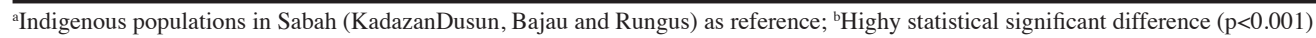


2012) populations. Additionally, $c 2$ allele was statistically significant associated with the occurrence of colorectal cancer in Hungarian (Kiss et al., 2007) population. The associations of CYP2E1 PstI polymorphism in Northern and Southern China for esophageal cancer differs (Wang et al., 2012). The association study of CYP2E1 PstI polymorphism in indigenous groups in Sabah differs from other populations as there was a significant difference in their genotype distributions. Therefore, this finding reflects the importance of taking these differences into account when discussing the genetic markers for diseases and drug response in Sabah ethnics and other populations (Persson et al., 1993).

In summary, no genotype distributions difference was observed among the three major indigenous Sabah populations of this study is also supported by genetic differentiation study using Alu insertions analysis in previous study (Kee et al., 2012). However, the genotype distributions of indigenous ethnics in Sabah differ from other Asian and non-Asian populations. This finding highlighted the significant of ethnic and geographical differences in the prevalence of $C Y P 2 E 1$ PstI polymorphism. Hence, it is important to establish the genotype distributions and allele frequencies of the indigenous populations in Sabah. The unique genotype distributions in these indigenous ethnic groups revealed in this study signifies the need to establish its own data set. Studies involving larger groups in future will provide more valuable information of the association between $C Y P 2 E 1$ polymorphisms to diseases susceptibility and drug effects in the different populations.

\section{Acknowledgements}

The authors would like to take this opportunity to thank all the staff at Blood Bank Unit, Hospital of Women and Children, Kota Kinabalu, Sabah for their assistance in this study. This study was supported by the University of Malaya Research Collaborative Grant CG 041-2013.

\section{References}

Agundez AGJ, Rodriguez I, Olivera M, et al (1997). CYP2D6, $N A T 2$ and $C Y P 2 E 1$ genetic polymorphisms in nonagenarians. Age Ageing, 26, 147-51.

An HR, Wu XQ, Wang ZY, et al (2012). NAT2 and CYP2E1 polymorphisms associated with antituberculosis druginduced hepatotoxicity in Chinese patient. Clin Exp Pharmacol Physiol, 39, 535-43.

Bolt HM, Roos PH, Their R (2003). The cytochrome P-450 isoenzyme $C Y P 2 E 1$ in the biological processing of industrial chemicals: consequences for occupational and environmental medicine. Int Arch Occup Environ Health, 76, 174-85.

Cai L, Yu SZ, Zhang ZF (2001). Cytochrome P450 2E1 genetic polymorphism and gastric cancer in Changle, Fujian province. World J Gastroenterol, 7, 792-5.

Costa GN, Magno LA, Santana CV, et al (2012). Genetic interaction between NAT2, GSTM1, GSTT1, CYP2E1, and environmental factors is associated with adverse reactions to anti-tuberculosis drugs. Mol Diagn Ther, 16, 241-50.

Cotterchio M, Boucher BA, Manno M, et al (2008). Red meat intake, doneness, polymorphisms in genes that encode carcinogen-metabolizing enzymes, and colorectal cancer risk. Cancer Epidemiol Biomarkers Prev, 17, 3098-107.

Danko IM, Chaschin NA (2005). Association of CYP2E1 gene polymorphism with predisposition to cancer development. Exp Oncol, 27, 248-56.

Deng X-D, Gao Q, Zhang B, et al (2014). Functional Pst I/Rsa I polymorphism in cytochrome $\mathrm{P} 4502 \mathrm{E} 1$ contributes to bladder cancer susceptibility: evidence from a meta-analysis. Asian Pac J Cancer Prev, 15, 4977-82.

Feng J, Pan X, Yu J, et al (2012). Functional Pst I/Rsa I polymorphism in $C Y P 2 E 1$ is associated with the development, progression and poor outcome of gastric cancer. PLoS One, 7, 44478.

Guo YM, Wang Q, Liu YZ, et al (2008). Genetic polymorphisms in cytochrome P4502E1, alcohol and aldehyde dehydrogenases and the risk of esophageal squamous cell carcinoma in Gansu Chinese males. World J Gastroenterol, 14, 1444-9.

Gupta VH,Amarapurkar DN, Singh M, et al (2013). Association of N-acetyltransferase 2 and cytochrome P450 2E1 gene polymorphisms with antituberculosis drug-induced hepatotoxicity in Western India. J Gastroenterol Hepatol, 28, 1368-74.

Hans JB, Craig S, Michael EB, et al (2008). Indigenous Groups of Sabah, An annotated Bibliography of linguistics and Anthropological Sources, SIL e-Books, (SIL International cooperation with the Govt. of the State of Sabah, Malaysia), XV-XVI.

Haufroid V, Buchet JP, Gardinal S, et al (2002). Cytochrome P4502E1 phenotyping by the measurement of the chlorzoxazone metabolic ratio: assessment of its usefulness in workers exposed to styrene. Int Arch Occup Environ Health, 75, 453-8.

Kee BP, Chua KH, Lee PC, et al (2012). Population data of six Alu insertions in indigenous groups from Sabah, Malaysia. Ann Hum Biol, 39, 505-10.

Kim RB, Yamazaki H, Chiba K, et al (1996). In vivo and in vitro characterization of CYP2E1 activity in Japanese and Caucasians. J Pharmacol Exp Ther, 279, 4-11.

Kiss I, Orsos Z, Gombos K, et al (2007). Association between allelic polymorphisms of metabolizing enzymes (CYP 1A1, CYP 1A2, CYP 2E1, mEH) and occurrence of colorectal cancer in Hungary. Anticancer Res, 27, 2931-7.

Kandasami P, Tan WJ, Norain K (2003). Gastric cancer in Malaysia: the need for early diagnosis. Med J Malaysia, $\mathbf{5 8}, 758-62$.

Küry S, Buecher B, Robiou-du-Pont S, et al (2007). Combinations of cytochrome $\mathrm{P} 450$ gene polymorphisms enhancing the risk for sporadic colorectal cancer related to red meat consumption. Cancer Epidemiol Biomarkers Prev, 16, 1460-7.

Kayaalti Z, Soylemezoglu T (2010). Distribution of $A D H 1 B$, $A L D H 2, C Y P 2 E 1 * 6$, and $C Y P 2 E 1 * 7 \mathrm{~B}$ genotypes in Turkish population. Alcohol, 44, 415-23.

Lakkakula S, Maram M, Munirajan AK, et al (2013). Functional $P s t \mathrm{I} / R s a \mathrm{I}$ polymorphisms in the CYP2E1 gene among south Indian populations. Asian Pac J Cancer Prev, 14, 179-82.

Lee SW, Chung LS, Huang HH, et al (2010). NAT2 and $C Y P 2 E 1$ polymorphisms and susceptibility to first-line anti-tuberculosis drug-induced hepatitis. Int J Tuberc Lung Dis, 14, 622-6.

Leete R (2008). Sabah's population size and composition, Sabah's Human Development Progress and Challenges, Jan 7 2008, UNDP. Available at http://www.scribd.com/ doc/2329023/UNDPSabah-Human-Development-Statistics (accessed 30 Dec 2013).

Lin DX, Tang YM, Peng Q, et al (1998). Susceptibility to esophageal cancer and genetic polymorphisms in glutathione 
The CYP2E1 PstI Polymorphism in Indigenous Groups in Sabah, Malaysia

S-transferases T1, P1, and M1 and cytochrome P450 2E1. Cancer Epidemiol Biomarkers Prev, 7, 1013-8.

Liu S, Park JY, Schantz SP, et al (2001). Elucidation of CYP2E1 5 ' regulatory $R s a \mathrm{I} / P s t I$ allelic variants and their role in risk for oral cancer. Oral Oncol, 37, 437-45.

Maezawa Y, Yamauchi M, Toda G (1994). Association between restriction fragment length polymorphism of the human cytochrome P450IIEI gene and susceptibility to alcoholic liver cirrhosis. Am J Gastroenterol, 89, 561-5.

McCord JM (1998). Iron, free radicals, and oxidative injury. Semin Hematol, 35, 5-12.

Nakazawa H, Genka C and Fujishima M (1996). Pathological aspects of active oxygen/free radicals. Jpn J Physiol, 46, 15-32.

Park GT, Lee OY, Kwon SJ, et al (2003). Analysis of $C Y P 2 E 1$ polymorphisms for the determination of genetic susceptibility to gastric cancer in Koreans. J Gastroenterol Hepatol, 18, 1257-63.

Persson I, Johansson I, Bergling H, et al (1993). Genetic polymorphism of cytochrome P4502E1 in a Swedish population. FEBS Letters, 319, 207-11.

Raunio H, Husgafvel, PK, Anttila S, et al (1995). Diagnosis of polymorphisms in carcinogen-activating and inactivating enzymes and cancer susceptibility - a review. Gene, 159, 113-21.

Rossini A, Rapozo DC, Soares Lima SC, et al (2007). Polymorphisms of GSTP1 and GSTT1, but not of CYP2A6, CYP2E1 or GSTM1, modify the risk for esophageal cancer in a western population. Carcinogenesis, 28, 2537-42.

Rundi C, Fielding K, Godfrey-Faussett P, et al (2011). Delays in seeking treatment for symptomatic tuberculosis in Sabah, East Malaysia: factors for patient delay. Int J Tuberc Lung Dis, 15, 1231-8.

Saeed HM, Alanazi MS, Nounou HA, et al (2013). Cytochrome P450 1A1, 2E1 and GSTM1 gene polymorphisms and susceptibility to colorectal cancer in the Saudi population. Asian Pac J Cancer Prev, 14, 3761-8.

Shahriary GM, Galehdari H, Jalali A, et al (2012). CYP2E1*5B, $C Y P 2 E 1 * 6, C Y P 2 E 1 * 7 \mathrm{~B}, C Y P 2 E 1 * 2$, and $C Y P 2 E 1 * 3$ allele frequencies in Iranian populations. Asian Pac J Cancer Prev, 13, 6505-10.

Uematsu F, Kikuchi H, Motomiya M, et al (1992). Human cytochrome P450IIE1 gene: DraI polymorphism and susceptibility to cancer. Tohoku J Exp Med, 168, 113-7.

van der Logt EMJ, Bergevoet SM, Roelofs HMJ, et al (2006). Role of epoxide hydrolase, NAD(P)Hquinone oxidoreductase, cytochrome P450 2E1 or alcohol dehydrogenase genotypes in susceptibility to colorectal cancer. Mutat Res, 593, 39-49.

Wang D, Su M, Tian D, et al (2012). Associations between $C Y P 1 A 1$ and $C Y P 2 E 1$ polymorphisms and susceptibility to esophageal cancer in Chaoshan and Taihang areas of China. Cancer Epidemiol, 36, 276-82.

Wang Y-D, Yang H-Y, Liu J, Wang H-Y (2014). Updated metaanalysis of the association between CYP2E1 Rsa I/Pst I polymorphisms and lung cancer risk in Chinese population. Asian Pac J Cancer Prev, 15, 5411-16.

Wise MR (2008). Indigenous groups of Sabah: an annotated bibliography of linguistic and anthropological sources. Malaysia: The Natural History Publications.

Wu D, Cederbaum AI (2005). Oxidative stress mediated toxicity exerted by ethanol-inducible CYP2E1. Toxicol Appl Pharmacol, 207, 70-6.

Wu X, Shi H, Jiang H, et al (1997). Associations between cytochrome P4502E1 genotype, mutagen sensitivity, cigarette smoking and susceptibility to lung cancer. Carcinogenesis, 18, 967-73.

Wu X, Amos CI, Kemp BL, et al (1998). Cytochrome P450 2E1
Dra I polymorphism in lung cancer in minority populations. Cancer Epidemiol Biomarkers Prev, 7, 13-8.

Yu MW, Gladek-Yarborough A, Chiamprasert S, et al (1995). Cytochrome P450 2E1 and glutathione S-transferase M1 polymorphisms and susceptibility to hepatocellular carcinoma. Gastroenterol, 109, 1266-73.

Zhuge J, Luo Y, Yu YN (2003). Heterologous expression of human cytochrome P450 2E1 in HepG2 cell line. World $J$ Gastroenterol, 9, 2732-6. 